\title{
Editorial
}

\section{SANDWiched between STRasbourg and KarlsRUhe: EU fundamental RIGHTS PROTECTION}

(E)in Staaten-, Verfassungs-, Verwaltungs- und Rechtsprechungsverbund, i.e. 'a union of states, constitutions, administrations and courts': that is how the German constitutional court, the Bundesverfassungsgericht, characterises the European Union in a judgment of 15 December 2015, ${ }^{1}$ as it repeated in its judgment of 21 June $2016 .^{2}$ In its decision on the Treaty of Maastricht of 12 October 1993, it already qualified the EU as a Statenverbund. Although it was clear that that term, new in legal discourse, expressed the view that the EU had to be situated somewhere in between a confederation (Staatenbund) and a federal state (Bundesstaat), the German Court did not explain what it exactly meant. This time it is similar: an explanation is lacking. However, a contribution to this journal in 2010 by Andreas Voßkuhle, the president of the second Senate of the Bundesverfassungsgericht that rendered the decision of 15 December, may provide a glimpse of what was meant. On the occasion of the introduction of yet another term, Verfassungsgerichtsverbund, to which we shortly return, Voßkuhle sketched the denotations and connotations that the use of the term Verbund in EU context evokes:

The concept of Verbund helps to describe the operation of a complex multilevel system without determining the exact techniques of the interplay. The term Verbund makes it possible to do without oversimplistic spatial and hierarchic concepts such as 'superiority' and 'subordination'. Instead, it opens up the possibility of a differentiated description on the basis of different systematic aspects such as unity, difference and diversity, homogeneity and plurality, delimitation, interplay and involvement. The idea of Verbund equally contains autonomy, consideration and ability to act jointly. ${ }^{3}$

If we apply this to the Bundesverfassungsgericht's new character sketch, we learn that it expresses the view that the EU is a non-hierarchical, composite multilevel

${ }^{1}$ BVerfG, 2 BvR 2735/14 of 15 December 2015, para. 44.

${ }^{2}$ BVerfG, 2 BvR 2728/13 of 21 June 2016, para. 140.

${ }^{3}$ A. Voßkuhle, 'Multilevel cooperation of the European Constitutional Courts: Der Europäische Verfassungsgerichtsverbund', 6 EuConst (2010) p. 175 at p. 183-184. 
structure in which states, constitutions, administrations and courts cooperate and have the ability to act jointly, while mutually respecting each other and accommodating and reconciling such contradictory imperatives as unity and diversity, or homogeneity and plurality. This character sketch seems to have a primarily normative function: it helps the Bundesverfassungsgericht to defy the unconditional primacy of EU law and to justify that it may in exceptional cases and subject to strict conditions' declare an act of the EU to be inapplicable in Germany. ${ }^{4}$ At the same time, it seems a very apt description of how the EU functions in practice.

Something similar may be said of the term which Voßkuhle introduced in his contribution to this journal: europäischer Verfassungsgerichtsverbund, i.e. a 'multilevel cooperation of the European constitutional courts'. This term seems to be a cross between, or at least to overlap with, the terms Verfassungsverbund and Rechtsprechungsverbund. Indeed, as constitutions cannot speak and act for themselves, they need a spokesperson, and in most member states it is the constitutional court that is the mouthpiece of the constitution, to paraphrase Montesquieu. Voßkuhle's Verfassungsgerichtsverbund consists of three European constitutional courts interacting in a 'cooperative, non-hierarchical handling of multilevel constitutional issues': the Bundesverfassungsgericht as the mediator between the Basic Law and the European legal system', the Court of Justice of the European Union 'as the drafter of European legal unity' and the European Court of Human Rights 'as the guardian of the European Convention on Human Rights'. We immediately add that we think that Voßkuhle does not mean to imply that this system is necessarily closed and limited to these three courts only: the Verbund is undoubtedly also open to other national constitutional courts, if they too want to play a role in it. Indeed, Voßkuhle's view must be understood to refer to national constitutional courts in general - although the German constitutional court is a dominating one within the European legal area, as the suspense and relief surrounding the OMT judgment of 21 June 2016 confirms. Imagine how the collapse of the financial markets could have developed after the UK's EU membership referendum, had the German court declared the Outright Money Transactions instrument to be unconstitutional two days earlier.

Just like the other characterisations of the EU in terms of a Verbund, the term Verfassungsgerichtsverbund seems to have normative and descriptive implications: normative, because each court has to be allowed to play its proper role within this non-hierarchical and multilevel system of courts; descriptive, as the term also turns out to be an apt description of the ability of the European Court of Human Rights, the European Court of Justice and national constitutional courts to determine the design of the EU legal order by their interaction. This is illustrated

\footnotetext{
${ }^{4}$ BVerfG, 2 BvR 2735/14 of 15 December 2015, para. 44.
} 
by two recent judgments. They show the Verbund in full swing, determining the level of EU fundamental rights protection. They also testify to the fact that the European Court of Justice, despite its insistence on the autonomy and primacy of EU law, is in reality sandwiched between the demands of the ECHR and those of the Basic Law, and is pushed and pulled by the respective spokespersons of the latter towards a high standard of fundamental rights protection. The first judgment we discuss is the judgment of the Bundesverfassungsgericht of 15 December 2015 we mentioned, the second is of the European Court of Justice and dated 5 April 2016.

The Bundesverfassungsgericht's judgment of 15 December 2015, concerning the surrender to another member state under a European arrest warrant of a person convicted in absentia, clarifies several outstanding issues concerning the relationship between German constitutional law and EU law and is a treasure trove for constitutional identity diggers. The most important issue that is clarified concerns the relationship between the Solange II/Bananas case law, on the one hand, and constitutional identity review, on the other. As is well known, under the Solange II/Bananas case law the Court refuses to take up a complaint that a German fundamental right is violated on the basis of an EU act, unless the individual complainant (or the referring German court) 'proves' that the general level of fundamental rights protection in the $\mathrm{EU}$ is no longer equivalent to that provided under the Basic Law. ${ }^{5}$ In its judgment on the Lisbon Treaty and subsequent case law, however, the Court suggested at least a partial return to the Solange I case law, ${ }^{6}$ by identifying certain fundamental rights particles of German constitutional identity: the nullum crimen sine culpa principle ${ }^{7}$ and the principle that the 'citizens' enjoyment of freedom may not be totally recorded and registered'. ${ }^{8}$ The Court now confirms that two strands of fundamental rights case law do indeed coexist. If an individual complainant demonstrates in detail that in the case at hand, an EU act violates the guarantee of human dignity as protected by Article 1 of the German Basic Law, the complaint will be admissible because human dignity is part of the constitutional identity of the Basic Law. ${ }^{9}$ The Court presents these admissibility criteria as creating a higher threshold than those under Solange II (erböhten Zülassigkeitsanforderungen). But one can think of this differently: after all, the complainant is discharged from the arduous task of having

${ }^{5}$ BVerfGE 73, 339 (Solange II); BVerfG, 2 BvL 1/97 of 06 July 2000 (Bananas).

${ }^{6}$ BVerfGE 37, 271 (Solange I).

${ }^{7}$ BVerfG, 2 BvE 2/08 of 30 June 2009 (Lisbon), para. 364.

${ }^{8}$ BVerfG, 1 BvR 256/08 of 2 March 2010 (Vorratsdatenspeicherung), para. 218.

${ }^{9}$ BVerfG, 2 BvR 2735/14 of 15 December 2015, para. 50: 'Es muss in Einzelnen substantiert dargelegt werden, inwieweit im Konkreten Fall die durch 1 GG geschützte Garantie der Menschenwürde verletzt ist'. 
to prove that the general level of fundamental rights protection in the EU has declined. However, the Bundesverfassungsgericht is undoubtedly right that instances of human dignity violations will rarely happen, ${ }^{10}$ at least when the German Court itself exercises restraint. ${ }^{11}$

It is impossible to miss the connection between the announced possibility of identity review in fundamental rights cases and the Melloni case law of the European Court of Justice: the Bundesverfassungsgericht itself provides the link. To recapitulate: the European Court of Justice in Melloni refused to allow member states to make the surrender of a person convicted in absentia conditional on the right to a retrial in the issuing member state, although according to the referring Spanish Constitutional Court, this right belonged to the core of the right to a fair trial in the Spanish Constitution and entailed the duty to respect human dignity. ${ }^{12}$ But according to the European Court of Justice, the limitative exceptions in the European Arrest Warrant Framework Decision, as amended in 2009, provide no room for such refusal in cases of conviction in absentia where the accused was aware of the trial and was represented in court, while neither the ECHR nor the EU Charter of Fundamental Rights demand this, and the principle of primacy of EU law rules out that the validity or applicability of secondary EU law may be affected by contrary national constitutional law. ${ }^{13}$ The Spanish Court accepted the decision on 13 February 2014 and changed its interpretation of the relevant constitutional provision, while indicating, as it had done before, that its reservoir of obedience is not unlimited: if the development of EU law were to be incompatible with the Spanish Constitution, the protection of Spanish sovereignty and the supremacy of the Spanish Constitution would require it to decide in favour of the latter. ${ }^{14}$ One wonders why that situation did not materialise in Melloni: after all, in the Spanish Court's view, nothing less than the core of a fundamental right was at stake. But apparently it was not convinced that in this case, the game was worth the candle.

The Bundesverfassungsgericht's present judgment also concerns a surrender for the execution of a sentence rendered in absentia in Italy (to 30 years' imprisonment for membership of a criminal organisation and the possession of cocaine). In contrast to the Spanish Court, the German Court is not willing to

\footnotetext{
${ }^{10}$ Idem, para. 46.

${ }^{11}$ H. Sauer, "'Solange” geht in Altersteilzeit - Der unbedingte Vorrang der Menschenwürde vor dem Unionsrecht', 69 NJW (2016) p. 1134 at p. 1136.

${ }^{12}$ A. Torres Pérez, 'Spanish Constitutional Court, Constitutional Dialogue on the European Arrest Warrant: The Spanish Constitutional Court Knocking on Luxembourg's Door; Spanish Constitutional Court, Order of 9 June 2011 ATC 86/2011', 8 EuConst (2012) p. 105 at p. 108.

${ }^{13}$ ECJ 5 April 2013, Case-399/117, Melloni.

${ }^{14}$ Spanish Constitutional Court, STC 26/2014 of 13 Feb. 2014. See A. Torres Pérez, Melloni in Three Acts: From Dialogue to Monologue', 10 EuConst (2014) p. 308.
} 
compromise when fundamental principles of the German constitution are at stake: it stuck to its case law and applied it to surrender requests. The principle of nulla poena sine culpa is anchored in the guarantee of human dignity provided for in Article 1 of the Basic Law, which is part of German constitutional identity. ${ }^{15}$ It requires, in principle, that an accused's blameworthiness has been determined by a competent court before he or she is convicted. To this end, certain minimum standards for accused persons in criminal proceedings have to be met: they have to be able to present circumstances that may be exonerating or relevant for sentencing during trial in court. These minimum guarantees have to be observed not only in national criminal proceedings and in classical extradition proceedings, but also in the context of the European Arrest Warrant Framework Decision: the principle of mutual trust that governs extradition in the Union is limited by the guarantee of human dignity in Article 1. Therefore, if a person whose surrender is sought and who has been tried in absentia adduces that his minimum rights of defence, as guaranteed by Article 1, are not effectively ensured in the issuing state, the relevant German authorities have to investigate the issue, and they have to refuse to surrender if it turns out that the convict is right, even if the Court of Justice were to dictate otherwise. ${ }^{16}$

However, the Bundesverfassungsgericht found it did not need to exercise an identity review in the case at hand. It found that European Union law was completely in line with German constitutional identity. Not only the European Arrest Warrant Framework Decision, but also the Charter of Fundamental Rights of the Union as interpreted in the light of the ECHR required in this case that the requested person was guaranteed a retrial in the issuing state. Preliminary questions to the European Court of Justice were not necessary because the 'correct application' of Union law in this case was so obvious that there is 'no room whatsoever for any reasonable doubt' (für einen vernünftigen Zweifel [bleibt] keinerlei Raum). ${ }^{17}$

This judgment is not necessarily incompatible with Melloni: in contrast to the latter case, in the German case the convict had been unaware of the pending trial, as a consequence of which other provisions of the Framework Decision were at stake than in Melloni. Probably, the European Court of Justice would have come

\footnotetext{
${ }^{15}$ BVerfG, 2 BvR 2735/14 of 15 December 2015, para. 53.

${ }^{16}$ Idem, para. 82 and 83: in para. 82 the Court repeats the essence of the Melloni ruling, while in para. 83 it states that this 'does not absolve German authorities and courts from the duty to ensure the observance of the principles of Art. 1 of the Basic Law, also in cases of surrender in the execution of a European Arrest Warrant', i.e. when constitutional identity is at stake. Note, however, that Melloni is silent as to a possible exception for an exception to constitutional identity, particularly in light of the opinion of the Advocate General in Melloni, see L.F.M. Besselink, 'Parameters of Constitutional Conflict after Melloni', 39 European Law Review (2014) p. 547-549.

${ }^{17}$ Para. 125.
} 
to the same interpretation of the relevant EU provisions if it had been given the chance to speak before the German Court did. This is all the more likely because the EU legislature, in a Directive of 9 March 2016 which has to be implemented on 1 April 2018, obliges all member states generally to provide 'the right to a new trial' if a person tried in absentia was unaware of the trial. ${ }^{18}$ But as things stand now, the German Court puts the European Court of Justice on the spot. It does so by using an inbuilt escape clause in the order of succession of constitutional courts in the European constitutional order that is generally followed in practice. The order is that the European Court of Justice must first have had its say before a national constitutional court may rule on an alleged conflict between EU and national law. This order, articulated in the acceptance in principle and the increasing use of the preliminary procedure by national constitutional courts, is reaffirmed by the German Court in the present judgment: also when it exercises identity review, it will do so on the basis of the interpretation given by the European Court of Justice, at least 'when this is necessary' (soweit erforderlich). ${ }^{19}$ This order of succession has been deemed acceptable to the courts involved, inter alia because the national constitutional courts keep the last word, at least formally, while the Court of Justice could find solace in the acknowledgement that the one who has préséance is the more important one. ${ }^{20}$ But here exactly is where the shoe pinches for a national constitutional court that really wants to make a difference: the order of succession places it in a difficult position. If it uses its last word to declare an EU act as interpreted by the European Court of Justice incompatible with national fundamental constitutional principles, it will be blamed for disturbing the European legal peace. This is witnessed by the almost unanimous criticism the Czech Constitutional Court's Landtova judgment has received in EU literature, and equally by the almost unanimous condemnation of the announcement of the mere possibility of ultra vires and constitutional identity review by the Bundesverfassungsgericht, which has turned the German Court into the black sheep of EU scholarship.

Against this backdrop, the judgment of 15 December 2015 is a tactical masterstroke. By relying on an acte clair, backed up by the threat of an identity review, the Bundesverfassungsgericht reverses the order of succession: the European Court of Justice has the last word, but actually no room for manoeuvre once it is confronted with a preliminary question which requires it to make a choice. For if it were to disagree with the German Court's interpretation, it would be the one

${ }^{18}$ Arts. 8 and 9 of Directive (EU) 2016/343 of the European Parliament and of the Council of 9 March 2016 on the strengthening of certain aspects of the presumption of innocence and of the right to be present at the trial in criminal proceedings.

${ }^{19}$ BVerfG, 2 BvR 2735/14 of 15 December 2015, para. 46.

${ }^{20}$ WTE and JHR, 'Editorial: The Dance of Justice', 9 EuConst (2013) p. 1 at p. 4. 
disturbing the peace and being the cause of the German Court biting through. The odds are that that will not happen and that the European Court of Justice instead will be tacitly 'inspired' by the German Court's interpretation. ${ }^{21}$

More generally, the prospected constitutional identity review in individual fundamental rights cases ensures that the Bundesverfassungsgericht can have a finger in the pie as regards the upper level of EU fundamental rights protection. If the German court takes up an individual complaint and subsequently asks preliminary questions because it is not 'clair' or 'éclairé' that EU law, interpreted in light of the ECHR, meets the demands of human dignity under the German Basic Law, the European Court of Justice will know what is at stake if its interpretation of what EU law requires were not to follow the line set out by the German Court: the unity of application of EU law. Unless the Court interprets EU law to allow for diversity - which is the case generally for public policy restrictions in free movement cases, and when secondary law explicitly allows for it - the prospect of constitutional identity review generally requires the European Court of Justice to aspire to a high level of fundamental rights protection. This is not new; witness Kadi I and Schrems, in which the European Court of Justice respectively defended the constitutional identity of the EU vis-à-vis the international legal order and proclaimed that access on a generalised basis of public authorities to digital data compromises 'the essence of the fundamental right to respect for private life. ${ }^{22}$

Now for the European Court of Justice judgment of 5 April 2016. The Regional Higher Court of Bremen, Germany, asked whether Article 1(3) of the European Arrest Warrant Framework Decision precludes the execution of arrest warrants for the purpose of a criminal prosecution or the execution of a custodial sentence if there are strong indications that the detention conditions in the issuing member state infringe the fundamental rights of the persons concerned and the

\footnotetext{
${ }^{21}$ This seems to be confirmed by the judgment of 24 May 2016 in Case C-108/16 PPU, Dworzecki, on a preliminary reference by the District Court of Amsterdam. The ECJ allows the executing court to review whether the convict had been notified of the trial in person (Art. 4bis (1)(a)(i) EAWFD); if not, the surrender can be refused in the absence of a right to retrial after a conviction in absentia. In the Netherlands it must then be refused, as a consequence of the right to a fair trial and legal certainty; see the follow-up judgment of the District Court Amsterdam, 16 June 2016, ECLI:NL:RBAMS:2016:3643. Idem in Germany on the basis of BVerfG, 2 BvR 2735/14 of 15 December 2015: had the ECJ prohibited the executing court to ascertain the personal notification of the trial, this would probably lead to an infringement of human dignity.

${ }^{22}$ Resp. ECJ 3 September 2008, Case C-402/05 P and C-415/05 P Kadi and Al Barakaat International Foundation v Council and Commission); ECJ 6 October 2015, Case C-362/14, Maximillian Schrems v Data Protection Commissioner; see also T. Ojanen in his case-note on Schrems in this issue ('Making the Essence of Fundamental Rights Real: The Court of Justice of the European Union Clarifies the Structure of Fundamental Rights under the Charter; text before note 15 and before note 23).
} 
fundamental legal principles as enshrined in Article 6 TEU. The referring court's particular concern was when issuing states (in casu Hungary and Romania) have been convicted in pilot judgments by the European Court of Human Rights because of their inhuman or degrading (in the sense of Article 3 ECHR) prison conditions, ${ }^{23}$ while there is a positive obligation of states to ensure that any prisoner is detained in conditions which guarantee the required respect for human dignity. ${ }^{24}$ The European Court of Justice reformulated the question: the Bremen court essentially asked whether a surrender request must be refused when 'there is solid evidence that detention conditions in the issuing Member State are incompatible with fundamental rights, in particular with Article 4 of the Charter', thus explicitly linking it to the duty to respect human dignity. ${ }^{25}$

The European Court of Justice had some room for manoeuvre, but not much: a 'no' would have undermined the fundamental constitutional principle governing the wider European legal sphere of the Convention, including the member states and the EU, i.e. the principle that the ECHR provides a minimum level of fundamental rights protection, a principle that is also expressed in Article 52(3) of the Charter. It declared that 'the prohibition of inhuman or degrading treatment or punishment (...) is absolute in that it is closely linked to respect for human dignity, the subject of Article 1 of the Charter. ${ }^{26}$ Subsequently, as the 'drafter of European legal unity', the European Court of Justice tried to make the best of it and provided procedural safeguards to protect the system of the Framework Decision from total collapse in relation to member states convicted by the European Court of Human Rights. The mere existence of systemic or generalised inhuman detention conditions in the issuing state is not sufficient to refuse surrender: the executing judicial authority has to verify, with the help of the issuing state, whether in the particular circumstances of the case the person concerned will run 'a real risk' of being subjected to inhuman treatment. If so, execution of the 'warrant must be postponed but it cannot be abandoned'. Moreover, the executing judicial authority may decide that the person concerned be held in custody, for as long as the right of liberty and security of person in Article 6, the presumption of innocence in Article 48, and the requirement of

${ }^{23}$ ECtHR 10 March 2015, Case Nos. 14097/12, 45135/12, 73712/12, 34001/13, 44055/13, and 64586/13, Varga and Others v Hungary; ECtHR 27 January 2015, Case Nos. 36925/10, 21487/12, 72893/12, 73196/12, 77718/12 and 9717/13, Neshkov and Others v Bulgaria.

${ }^{24}$ ECtHR 8 January 2013, Case Nos. 43517/09, 46882/09, 55400/09, 57875/09, 61535/09, $35315 / 10$ and 37818/10, Torreggiani and Others $\mathrm{v}$ Italy, para 65: 'l'article 3 fait peser sur les autorités une obligation positive qui consiste à s'assurer que tout prisonnier est détenu dans des conditions qui sont compatibles avec le respect de la dignité humaine'.

${ }^{25}$ ECJ 6 April 2016, Joint Cases C-404/15 and C-659/15 PPU, Pál Aranyosi and Robert Căladăraru, para. 74 and 85-88.

${ }^{26}$ Idem, para. 84. 
proportionality in Article 52(1) of the Charter allow. And if detention would not be allowed (or no longer be allowed), measures should be attached to the person's provisional release 'to prevent him from absconding and to ensure that the material conditions necessary for his effective surrender remain fulfilled for as long as no final decision on the execution of the European arrest warrant has been taken.' 27

In other words, the issuing state should in principle be given some time to improve before the final decision to refuse surrender may be taken. However, one wonders whether the mentioned Charter provisions, the substance of which are co-determined by similar principles in the ECHR and potentially also by the national courts such as the Bundesverfassungsgericht, would ever allow the relevant member states enough time to do the trick. Similarly, one wonders what the EU Council can do if it is informed by the issuing member state, as it should be, that its arrest warrants systematically ricochet, ${ }^{28}$ except of course exercise peer pressure and start an Article 7 TEU procedure. ${ }^{29}$ The time it takes to improve prison conditions can be expected to be longer than the proportional detention for surrender for a prosecution for the theft of $€ 900$ and for a conviction for driving without a driving licence, the two cases at issue in this judgment.

According to the European Court of Justice, the interpretation of EU fundamental rights has to be ensured 'within the framework of the structure and objectives of the EU'. ${ }^{30}$ Therefore member states may not demand from a member state issuing an European arrest warrant a higher level of fundamental rights than is provided for by EU law. Moreover, save in exceptional cases, they may not check whether the issuing state observes the fundamental rights guaranteed by the EU. ${ }^{31}$ In addition, the execution of the European arrest warrants may only be suspended 'in the event of a serious and persistent breach by one of the Member States of the principles set out in Article 6(1) EU, determined by the Council pursuant to Article 7(1) EU with the consequences set out in Article 7(2) EU'. ${ }^{32}$

These principles, which are consequences of the autonomy of the EU legal order, the primacy of EU law and the principle of mutual trust, are put into perspective by the two judgments discussed. They demonstrate that the EU legal

\footnotetext{
${ }^{27}$ Idem, para. 92-102.

${ }^{28}$ Idem, para. 99 and Art. 17 EAWFD.

${ }^{29}$ See further, M. Guiresse, 'Confiance mutuelle et mandat d'arrêt européen: évolution ou inflexion de la Cour de justice ?', <www.gdr-elsj.eu/2016/04/12/cooperation-judiciaire-penale/ confiance-mutuelle-et-mandat-darret-europeen-evolution-ou-inflexion-de-la-cour-de-justice/ $>$, visited 10 June 2016.

${ }^{30}$ ECJ 18 December 2014, Opinion 2/13, para. 170.

${ }^{31}$ Idem, para. 192.

${ }^{32}$ ECJ 9 May 2013, Case C-168/13 PPU, Jeremy F., para. 49.
} 
order is de facto and de jure far less autonomous than the European Court of Justice pretends it to be, both in relation to the national law of the member states and to international legal order. In reality, it is sandwiched between the demands of the ECHR and the German Basic Law. The European Court of Human Rights and the Bundesverfassungsgericht guide the EU to a higher level of EU fundamental rights protection than the European Court of Justice, as the traditional patron of the effectiveness of EU law, and the Court's integration instruments tend to be inclined to provide. The European Court of Human Rights ensures that the level of protection in the EU does not fall below a certain minimum; ${ }^{33}$ and the Bundesverfassungsgericht forces the Court of Justice to aspire to a still-higher level of protection if EU law, interpreted in light of the ECHR, does not meet the demands of human dignity under the German Basic Law - 'forces' it, at least, to the extent that the Court of Justice does not want to jeopardise the unity of EU law.

JHR/LB

${ }^{33}$ See also ECtHR 26 May 2016, Case No. 17502/07 Avotiņšv Latvia, para. 116: 'the Court must satisfy itself $(\ldots)$ that the mutual recognition mechanisms do not leave any gap or particular situation which would render the protection of the human rights guaranteed by the Convention manifestly deficient.' 